Walsh (physical chemistry) and Dr. A. S. Leah (applied thermodynamics). E. W. F. Seymour has been appointed lecturer in the Department of Physics.

\section{Geological Society: Officers and Council}

THE officers and council of the Geological Society have been elected for the ensuing year, as follows: President, Prof. W. B. R. King; Vice-Presidents, Dr. O. M. B. Bulman, Dr. L. R. Cox, Prof. L. Hawkes and Dr. G. M. Lees; Secretaries, Prof. S. E. Hollingworth and Mr. A. J. Butler ; Foreign Secretary, Prof. O. T. Jones; Treasurer, Mr. P. Evans; Council, Dr. S. Buchan, Dr. O. M. B. Bulman, Mr. A. J. Butler, Dr. G. F. Claringbull, Dr. L. R. Cox, Mr. H. G. Dines, Mr. P. Evans, Dr. W. F. Fleet, Prof. L. Hawkes, Prof. S. E. Hollingworth, Dr. R. G. S. Hudson, Prof. O. T. Jones, Prof. W. Q. Kennedy, Prof. W. B. R. King, Dr. J. F. Kirkaldy, Dr. G. M. Lees, Dr. W. A. Macfadyen, Prof. L. R. Moore, Miss H. M. Muir-Wood, Dr. J. S. Sandford, Prof. J. H. Taylor, Dr. H. D. Thomas and Dr. A. K. Wells.

\section{The Night Sky in July}

NEw moon occurs on July 11d. 02h. 28m., U.T., and full moon on July $26 \mathrm{~d} .12 \mathrm{~h} .20 \mathrm{~m}$. The following conjunctions with the moon take place: July $7 \mathrm{~d}$. 13h., Venus $8^{\circ}$ S.; July 8d. 11h., Jupiter $5^{\circ} \mathrm{S} . ;$ July 12d. 15h., Mercury $3^{\circ}$ S. ; July 19d. 01h., Saturn $8^{\circ} \mathrm{N}$. At the beginning of the month Mercury sets at $21 \mathrm{~h} .30 \mathrm{~m}$.; but it approaches the sun too closely to be seen for the greater part of the month and is in inferior conjunction on July 25 . Venus is a morning star, rising at $1 \mathrm{~h}$. $30 \mathrm{~m}$. on July 1 and about $1 \mathrm{~h} .10 \mathrm{~m}$. at the middle and end of the month; the visible portion of the illuminated disk varies from 0.54 to 0.67 , and its stellar magnitude averages -- 3.7 during the month. Mars is too close to the sun to be favourably observed. Jupiter is a morning star, rising at $2 \mathrm{~h} .05 \mathrm{~m}$., $1 \mathrm{~h} .20 \mathrm{~m}$. and $0 \mathrm{~h} .30 \mathrm{~m}$. on July 1, 15 and 31, respectively, and is moving eastward in the constellation Taurus. Saturn sets at $0 \mathrm{~h} .15 \mathrm{~m} ., 23 \mathrm{~h} .20 \mathrm{~m}$. and $22 \mathrm{~h} .20 \mathrm{~m}$. at the beginning, middle and end of the month, respectively, and is moving eastward in the constellation Virgo, stellar magnitude about 1 . On July 11 there will be a partial eclipse of the sun, of greatest magnitude $0 \cdot 201$, but it is invisible at Greenwich. On July 26 there will be a total eclipse of the moon, also invisible at Greenwich; the beginning will be visible generally in North America, South America, Antarctica, the Pacific Ocean, Australasia and the extreme northeastern parts of Asia, and the end generally visible in the Pacific Ocean, the north-western tip of North America, Australia, Antarctica, the Indian Ocean, and eastern and central Asia. Occultations of stars brighter than magnitude 6 are as follows, observations being made at Greenwich: July 3d. 0h. 10.8m., 22 Pisc. $(R)$, and July $30 \mathrm{~d}$. $3 \mathrm{~h} .12 \cdot 1 \mathrm{~m} ., \lambda$ Pisc. $(R)$; $R$ refers to reappearance.

\section{Announcements}

H.R.H. THE DUKE OF EDINBURGH has been pleased to accept honorary fellowship of the Institute of Welding.

ThE Minister of Fuel and Power has appointed Sir George Thomson to be chairman of his Scientific Advisory Council in succession to Sir Alfred Egerton, who retires at the end of June when his term of office expires. He has also appointed Mr. Kenneth Gordon, director-general of ordnance factories, Ministry of Supply, to be a member of the Council.
Dr. B. P. Uvarov, director of the Anti-Locust Research Centre, London, has been elected an honorary member of the Nederlandsche Entomologische Vereeniging, in recognition of his services to entomological science and for his contributions to the study of the Orthoptera in particular.

THE following have been appointed to lectureships in the University College of North Staffordshire: Dr. D. E. Davies (physics) and Dr. A. H. Wallace (mathematics)

THe annual Machinery and Implement Exhibition of the Sports Turf Research Institute (Bingley, Yorks) will be held on the sports grounds of Lever Bros., Port Sunlight, Wirrall, Cheshire, during July 1-2. A wide range of modern turf machinery, implements and ancillary equipment will be shown, as well as a display illustrating the scientific and educational work of the Institute. The Exhibition is only open to affiliated clubs and subscribers to the Institute.

THE thirtieth meeting of the Australian and New Zealand Association for the Advancement of Science is to be held in Canberra, during January 13-20, 1954. Further information can be obtained from the Association, Science House, 157 Gloucester Street, Sydney, New South Wales, or from Dr. C. Barnard, honorary local secretary of the Association, Box 109, City, Canberra, A.C.T., Australia.

THE Society for Experimental Biology is holding a symposium on "Active Transport" at Bangor, Caernarvonshire, during July 13-17. The speakers will include: Th. Rosenberg, H. Davson, J. A. Ramsay, J. R. Robinson, J. A. Kitching, D. C. Spanner, J. W. L. Beament, E. F. Gale, W. Wilbrandt, P. G. LeFevre, A. Rothstein, A. C. Frazer, F. W. R. Brambell, W. A. Hemmings, M. Maizels, I. J. Harris, J. F. Sutcliffe, H. Lundegårdh, R. Scott Russell, F. C. Steward, H. H. Ussing, R. D. Keynes, A. L. Hodgkin, E. J. Conway, R. E. Davies, H. B. Steinbach, J. F. Danielli. Those wishing to attend should write to Dr. D. J. Crisp, Marine Biological Station, University College of North Wales, Bangor, Caerns.

TнE following conferences in physics have been arranged in England in the week following the meeting in London during July 8-9, 1954, of the General Assembly of the International Union of Physics : a conference on experimental and theoretical nuclear physics during July 13-17, 1954, in the University of Glasgow ; a conference on the physics of the solid state, with special reference to defects in solids, during July 13-17, 1954, in the University of Bristol. Both conferences are arranged in co-operation with the International Union of Physics. Further information will be published in due course.

THE Textile Institute is offering a bursary, of value

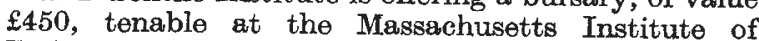
Technology, for nine months from September next until May 1954. The bursary, offered under the terms of the Frank Wright Memorial Fund, is open to associates of the Institute of British nationality, and is intended to enable the successful candidate to undertake a broad programme of study and research into problems concerning cotton spinning, doubling and twisting. Particulars can be obtained from the General Secretary, Textile Institute, 10 Blackfriars Street, Manchester 3; completed applications must be received by July 9 . 